\title{
Pseudohypoparathyroidism type 1a with hypomethylation at the responsible differentially methylated region for Beckwith-Wiedemann syndrome
}

\author{
Yoshiaki Ohtsu ${ }^{1 *}$, Kanako Kurata ${ }^{1}$, Mai Takahashi ${ }^{1}$, Takanori Kowase', Hirokazu Arakawa', Shinichiro Sano ${ }^{2}$, \\ Masayo Kagami ${ }^{2}$
}

From 8th APPES Biennial Scientific Meeting

Darwin, Australia. 29 October - 1 November 2014

\begin{abstract}
Aim
It was previously reported that several patients with pseudohypoparathyroidism type 1b (PHP-1b) have a more generalised imprinting defect. However there was no report that a patient of PHP-1a has any generalised imprinting defects. Here we aim to report a case of PHP-1a with hypomethylation at the Kv-differentially methylated region (DMR) (11p15.5), responsible for Beckwith-Wiedemann syndrome.
\end{abstract}

\section{Method}

A 6-year-old girl admitted to our hospital because of tetany due to hypocalcemia.

\section{Result}

She was a full-term infant and was delivered after an uncomplicated pregnancy. She did not show macrosomia, omphalocele or macroglossia. The neonatal period was uncomplicated. Her TSH level was in the normal range on neonatal screening. Her parents and younger sister did not show any visible sign of Albright's hereditary ostedystrophy. At 5 months old, she was severely obese and clinical follow-up was started. At 2 years old, her serum TSH level was $11.8 \mathrm{IU} / \mathrm{l}$ and free T4 was $0.4 \mathrm{ng} / \mathrm{dl}$. Her serum calcium level and phosphate level were within normal ranges. She was diagnosed as having hypothyroidism and levothyroxine replacement therapy

${ }^{1}$ Gunma University Graduate School of Medicine, Department of Pediatrics, Maebashi, Japan

Full list of author information is available at the end of the article was initiated. Her body weight then gradually decreased. She did not suffer from mental retardation.

At 6 years old, she was admitted to our hospital because of tetany when she had an upper urinary tract infection. On admission to our hospital, she presented with a round chubby face, short neck and obesity. Radiography indicated short metacarpals, which mainly affected the fourth digit. Computed tomography indicated ectopic ossifications at putamen. Biochemistry revealed hyperphosphatemia and increased serum concentrations of parathyroid hormone. Urinary excretions of cAMP and phosphate did not increase after intravenous infusion of PTH, suggesting PTH resistance in the kidney. Molecular analysis revealed a maternally inherited $2-\mathrm{Mb}$ deletion of 20q13.3-20q13.32 including the GNAS locus and the adjacent STX16 locus. Furthermore, a loss of maternal methylation on the Kv-DMR region was detected. A specific diagnosis was made of PHP-1a in the presence of Beckwith-Wiedemann syndrome. She was treated with 1,25-dihydroxyvitamin D3 [1,25(OH $)_{2}$ D3] $(0.02 \mu \mathrm{g} / \mathrm{kg} /$ day $)$ and calcium lactate $(0.1 \mathrm{~g} / \mathrm{kg} /$ day $)$ was initiated. By this treatment, hypocalcemia was improved. Serum intactPTH level has gradually decreased to $100-200 \mathrm{pg} / \mathrm{ml}$. Her urinary calcium excretion has remained below 0.2 (calcium $(\mathrm{mg} / \mathrm{dl}) /$ creatinine $(\mathrm{mg} / \mathrm{dl})$.

\section{Conclusions}

This is the first case report to describe a combination of PHP1a with a generalised imprinting defect, and their coexistence should be considered and further investigated.

Written informed consent was obtained from the patient for publication of this abstract and any accompanying 
images. A copy of the written consent is available for review by the Editor of this journal.

\section{Authors' details}

'Gunma University Graduate School of Medicine, Department of Pediatrics,

Maebashi, Japan. ${ }^{2}$ National Research Institute for Child Health and

Development, Department of Molecular Endocrinology, Tokyo, Japan.

Published: 28 April 2015

doi:10.1186/1687-9856-2015-S1-051

Cite this article as: Ohtsu et al:: Pseudohypoparathyroidism type 1a

with hypomethylation at the responsible differentially methylated region for Beckwith-Wiedemann syndrome. International Journal of

Pediatric Endocrinology 2015 2015(Suppl 1):051.

Submit your next manuscript to BioMed Central and take full advantage of:

- Convenient online submission

- Thorough peer review

- No space constraints or color figure charges

- Immediate publication on acceptance

- Inclusion in PubMed, CAS, Scopus and Google Scholar

- Research which is freely available for redistribution

Submit your manuscript at www.biomedcentral.com/submit 